\title{
Screening and characterization of sponge-associated bacteria from Seribu Island, Indonesia producing cellulase and laccase enzymes
}

\author{
WENANG MAHARSIWI, RIKA INDRI ASTUTI, ANJA MERYANDINI, ARIS TRI WAHYUDI \\ Division of Microbiology, Department of Biology, Faculty of Mathematics and Natural Sciences, Institut Pertanian Bogor. Jl. Raya Dramaga, Kampus \\ IPB, Bogor 16680, West Java, Indonesia. Tel./fax.: +62-251-8622833, •email: aristri2011@gmail.com
}

Manuscript received: 19 December 2019. Revision accepted: 9 February 2020.

\begin{abstract}
Maharsiwi W, Astuti RI, Meryandini A, Wahyudi AT. 2020. Screening and characterization of sponge-associated bacteria from Seribu Island, Indonesia producing cellulase and laccase enzymes. Biodiversitas 21: 975-981. Exploration of new enzymes from an extreme environment is important to improve industrial efficiency. This study aimed to get sponge-associated bacteria from Seribu Island with the capability to produce cellulase and laccase. These enzyme activities were indicated by the clear zones on CMC medium for cellulase and the reddish-brown zone on Guaiacol medium for laccase. About 100 of sponge-associated bacteria have been isolated from 5 marine sponges used SWC and NA modified media. As screened, one isolate (AGN89) could produce both enzymes and 11 isolates could produce cellulase. Quantitative analysis was performed using the DNS method and obtained the activities of 4 best cellulolytic isolates ranged from $0.04-0.06 \mathrm{UmL}^{-1}$ and $0.70-1.18 \mathrm{UmL}^{-1}$ in enzyme and specific activities, respectively. Gene-based determination for the isolate producing laccase resulted in a \pm 1100 bp amplicon fragment which identified as multicopper oxidase family protein. Based on the 16S-rRNA gene, AGN89 and these 4 cellulolytic isolates were identified as Pseudomonas luteola strain NBRC 103146, Bacillus aerius strain 24k, Pseudomonas aeruginosa strain DSM 50071, Mycobacterium maritypicum strain DSM 20578, and Brachybacterium conglomeratum strain J 1015. This result suggests that the sponge-associated bacteria from Seribu Island could become new enzymes producer for further applications in industry.
\end{abstract}

Keywords: 16S-rRNA, marine, cellulase, laccase, sponge-associated bacteria

\section{INTRODUCTION}

Cellulase and laccase have important roles in many industrial fields. As a hydrolysis enzyme, cellulase is widely used in various industries such as pulp and paper, textile, food and feed industry, brewing, and agriculture (Kuhad et al. 2011). Meanwhile, laccase is an enzyme with a very wide range of substrates and widely applied in many fields including decolorization of dyes, bleaching in the pulp and paper, chemical remediation, and synthesis of organic matter (Piscitelli et al. 2010). More importantly, these two enzymes also can be combined for lignocellulosic biomass degradation process, essential for paper industry and lignocellulose-based fuel industry. Cellulase enzymes, in general, are divided into many families, each of which can synergize in breaking down complex and non-complex cellulose polymers. Cellulase enzyme has been reported to be synthesized by bacteria, plants, and fungi. The corresponding protein structure of cellulase has also been comprehensively elucidated (Madadi et al. 2017). On the other hand, there are very few reports about laccase. The production of laccase can be found by soil and some freshwater fungi and are produced extracellularly (Chandra and Chowdhary 2015). Up to date, fungi have been the most widely reported source of laccase, yet, limited research has been performed in plants, bacteria, and insects.

The unique character of the enzyme used is a major consideration in determining its industrial application. Enzymes that are tolerant toward osmolarity stress, unstable $\mathrm{pH}$ and temperature, or the presence of solvents support their multipurpose industrial processes (Roth and Spiess 2015). Thus, the search for enzymes with unique characters is important. A great opportunity to discover new enzymes with unique physiological characters can be obtained through exploration in extreme environments, such as marine. Such diversity of character and extraordinary biocatalytic ability from marine obtained from micro- and macroorganisms is inflicted by marine harsh environment, extreme conditions, and strong selection due to the process of evolution. Various reports have proven that many marine-derived enzymes could be applied in diverse applications that accelerate bioprocesses efficiency (Sarkar et al. 2010). For instance, alkalihalotolerant and organic-solvent stable cellulases have been previously isolated from marine Bacillus sp. (Trivedi et al. 2011a). Other reports have also stated that the bacterial alkaline cellulase enzyme was successfully obtained from the marine sponge Dendrilla nigra (Shanmughapriya et al. 2010). However, just a few bacterial laccases have been biochemically characterized and none have been reported from marine organisms (Koschorreck et al. 2009).

Sponges are marine invertebrate organisms that have high biodiversity and can provide important niches for other organism trough symbionts, parasites, pathogens or commensals relationship. Many studies showed that microorganisms that associated with sponges have the ability to synthesize natural products similar to their host including enzymes, organic acid, and other metabolite compounds (Santos-Gandelman et al. 2014). In our previous study, sponge-associated bacteria isolated from 
the Raja Ampat islands of Papua, and the Seribu Islands in Jakarta exhibited the ability in producing antioxidants (Yoghiapiscessa et al. 2016), anti-cancer (Priyanto et al. 2017), antimicrobial (Wahyudi et al. 2018), and anti-aging (Prastya et al. 2019; 2020) compounds. In addition, it has also been reported that other marine bacteria can produce new potential enzymes with unique characteristics such as thermotolerant protease and alkalophilic amylase (Shanmughapriya et al. 2009). Thus, it is essential to explore new potential enzymes from tropical marine organisms, including which of Indonesian marine environments. Therefore, this research aimed to explore cellulase and laccase enzymes from sponge-associated bacteria of Kepulauan Seribu, Indonesia.

\section{MATERIALS AND METHODS}

\section{Procedures}

Isolation of sponge-associated bacteria

Sponges used in this study were collected from Seribu Island Jakarta, Indonesia. Five species of sponges, including Crella sp., Agelas sp., Callyspongia sp., Hyrtios sp. and Spongia sp., were used in this study. $1 \mathrm{~g}$ of each sponge tissue was washed by sterile seawater and ground in a mortar and pestle under aseptic conditions. The sample was homogenized and serially diluted in $9 \mathrm{~mL}$ of $0.85 \%$ $\left(\mathrm{WV}^{-1}\right) \mathrm{NaCl}$ solution from $10^{-1}$ to $10^{-4}$ level of dilution. About $100 \mu \mathrm{L}$ suspension of each serial dilution was plated into seawater complete (SWC) agar medium $\left(1 \mathrm{gL}^{-1}\right.$ yeastextract, $3 \mathrm{~mL}$ glycerol, $5 \mathrm{gL}^{-1}$ bactopeptone, $250 \mathrm{~mL}$ distilled water and $750 \mathrm{~mL}$ seawater, $15 \mathrm{gL}^{-1}$ agar) and modified nutrient agar (NA) medium $\left(5 \mathrm{gL}^{-1}\right.$ yeast-extract, $10 \mathrm{gL}^{-1}$ bactopeptone, $25 \mathrm{gL}^{-1} \mathrm{NaCl}, 15 \mathrm{gL}^{-1}$ agar) by spread plate technique. Plate was then incubated for 48 hours for SWC and 36 hours for NA media at room temperature $\left( \pm 27^{\circ} \mathrm{C}\right)$.

\section{Screening of cellulolytic bacteria}

Each bacterial isolates was cultured in NA medium and incubated for 24 hours at $27^{\circ} \mathrm{C}$ to prepare the main culture. Each isolate was further streaked onto the CMC agar plate (10 $\mathrm{gL}^{-1}$ carboxymethylcellulose, $2 \mathrm{gL}^{-1}$ bactopeptone, 1 $\mathrm{gL}^{-1}$ glucose, $0.2 \mathrm{gL}^{-1} 7 \mathrm{H}_{2} \mathrm{O} \cdot \mathrm{MgSO}_{4}, 0.75 \mathrm{gL}^{-1} \mathrm{KNO}_{3}, 0.5$ $\mathrm{gL}^{-1} \quad \mathrm{~K}_{2} \mathrm{HPO}_{4}, \quad 0.02 \quad \mathrm{gL}^{-1} \quad \mathrm{FeSO}_{4} \cdot 7 \mathrm{H}_{2} \mathrm{O}, \quad 0.04 \quad \mathrm{gL}^{-1}$ $\mathrm{CaCl}_{2} \cdot 2 \mathrm{H}_{2} \mathrm{O}$ ). The bacterial isolate incubated for 24 hours at room temperature and followed by reaction with Lugol's iodine reagent for 10 minutes. The cellulolytic index was calculated using the formula as follow:

$$
\text { Cellulolytic index }=\frac{\text { diameter of zone }- \text { diameter of colony }}{\text { diameter of colony }}
$$

\section{Screening of laccase-producing bacteria}

The activity of laccase in vitro was determined by monitoring the colored oxidation products on Guaiacol medium. Guaiacol $0.02 \%\left(\mathrm{vv}^{-1}\right)$ (Sigma, USA) was used as a substrate in NA medium (peptone $10 \mathrm{gL}^{-1}, \mathrm{NaCl} 10 \mathrm{gL}^{-1}$, yeast-extract $5 \mathrm{gL}-)$ and supplemented with $\mathrm{CuSO}_{4}(1 \mathrm{mM})$ (Chandra and Singh 2012). Bacterial isolates were streaked on the agar plate and were incubated for 2-3 days at room temperature.

\section{Quantitation of Cellulolytic activity by using DNS method}

Bacterial isolates were grown in $100 \mathrm{~mL}$ CMC broth ( $\mathrm{pH} \mathrm{7.0)} \mathrm{for} \mathrm{two} \mathrm{days} \mathrm{at} 27^{\circ} \mathrm{C}$ to prepare subculture. About $2 \mathrm{~mL}$ of subculture was then inoculated into a new $200 \mathrm{~mL}$ $\mathrm{CMC}$ liquid broth and incubated for 24 hours at $27^{\circ} \mathrm{C}$, which then used as the main culture. The main culture sample was harvested and its corresponding crude extract enzyme was obtained by centrifugation $(6,000 \times \mathrm{g}, 20$ minutes). Cellulolytic activity was measured by incubating $0.2 \mathrm{~mL}$ of crude enzyme solution with $0.5 \mathrm{~mL}$ of $1 \%\left(\mathrm{wv}^{-1}\right)$ carboxymethyl cellulose, prepared in $0.1 \mathrm{M}$ sodium phosphate buffer $(\mathrm{pH} 7.0$ ) for 10 minutes at room temperature. The reducing sugars were estimated by the 3.5-dinitrosalicylic acid (DNS) method (Miller 1959). The enzyme reaction was stopped by the addition of $3 \mathrm{~mL}$ DNS reagent (dinitrosalicylic acid $1 \mathrm{~g}, \mathrm{NaOH}, 16 \mathrm{~g}$, potassium sodium tartrate $300 \mathrm{~g}$, and distilled water up to $1 \mathrm{~L}$ ) to the above $1 \mathrm{~mL}$ reaction mixture, boiled in capped glass tubes for 5 minutes, and cooled in cold water, and then optical density was measured at $540 \mathrm{~nm}$. The enzyme activity was determined using a calibration curve for D-glucose. Meanwhile, the Bradford method is used to quantify the amount of protein involved in each enzyme activity measurement so that the value of the specific enzyme activity was obtained. One unit of enzyme activity was defined as the amount of enzyme that released $1 \mu \mathrm{mol}$ of reducing sugars as glucose equivalents per-minute. Four isolates with the best activity than were used for the next analysis.

\section{Determination of Laccase activity based on gene analysis}

Isolates were cultured in LB medium (yeast-extract, 5 $\mathrm{gL}^{-1}$; tryptone, $10 \mathrm{gL}^{-1} ; \mathrm{NaCl}, 10 \mathrm{gL}^{-1}$ ) for 24 hours in room temperature. The cultures were centrifuged at $10,000 \times$ gravitation for 1 minute, and the supernatant was removed. DNA extraction was performed using Presto ${ }^{\mathrm{TM}}$ Mini gDNA bacteria Kit (Geneaid) according to the protocol's instructions. For the detection of laccase gene, primer Cu1F ACM WCK GTT CAY TGG CAC GG and Cu4R TGN TCN AGN AWG TGR CAR TG were used to target \pm 1100 bp fragment (Fang et al. 2011). Fifty $\mu \mathrm{L}$ PCR mix consisted of $25 \mu \mathrm{L}$ GoTaq Green ${ }^{\circledR}$ Master Mix 123 (Promega), $5 \mu \mathrm{L}$ of $10 \mathrm{pmol} 1387 \mathrm{r}$ primer, $5 \mu \mathrm{L}$ of $10 \mathrm{pmol}$ 63f primer, $11 \mu \mathrm{L}$ nuclease-free water, and $4 \mu \mathrm{L}$ DNA template (100 ng $\left.\mu \mathrm{L}^{-1}\right)$ was prepared prior PCR. PCR conditions were carried out in three steps including predenaturation at $94^{\circ} \mathrm{C}$ for 5 minutes, followed by 35 cycles of denaturation at $94^{\circ} \mathrm{C}$ for 1 minute, annealing at $58^{\circ} \mathrm{C}$ for 1 minute, extension at $72^{\circ} \mathrm{C}$ for 1 minute, and final extension at $72^{\circ} \mathrm{C}$ for 10 minutes. The PCR products were checked by gel electrophoresis in $1 \%\left(\mathrm{wV}^{-1}\right)$ agarose gels stained with ethidium bromide $\left(10 \mathrm{mgmL}^{-1}\right)$ and PCR products were sequenced in First Base, Malaysia. The sequences were then compared to the database of the National Center for Biotechnology Information (NCBI) GenBank (https://www.ncbi.nlm.nih.gov) using the BlastX program. Construction of phylogenetic tree was constructed using MEGA 7.0 software by maximum 
likelihood method with $1000 x$ bootstrap replications.

\section{S rRNA gene Analysis}

The genomic DNA of bacterial isolates was prepared as described previously. The mixture of PCR reaction consisted of $50 \mu \mathrm{L}$ PCR mix containing $25 \mu \mathrm{L}$ GoTaq Green ${ }^{\circledR}$ Master Mix 123 (Promega), $5 \mu \mathrm{L}$ of $10 \mathrm{pmol}$ reverse primers, $5 \mu \mathrm{L}$ of 10 pmol forward primer, $11 \mu \mathrm{L}$ nuclease-free water, and $4 \mu \mathrm{L}$ DNA template $\left(100 \mathrm{ng} \mathrm{L}^{-1}\right)$. Bacterial universal primers 63F (5'-CAG GCC TAA CAC ATG CAA GTC-3') and 1387R (5'-GGG CGG WGT GTA CAA GGC-3') were used to amplify the 16S rRNA gene from genomic DNA which targeted \pm 1300 bp fragment (Marchesi et al. 1998). PCR conditions were carried out in 35 cycles with pre-denaturation at $94^{\circ} \mathrm{C}$ for 5 minutes, denaturation at $94^{\circ} \mathrm{C}$ for 30 seconds, annealing at $55^{\circ} \mathrm{C}$ for 45 seconds, extension at $72^{\circ} \mathrm{C}$ for 1 minute 45 second, and the final extension at $72^{\circ} \mathrm{C}$ for 10 minutes. The sequences were compared by using the BlastN program in National Center for Biotechnology Information (NCBI) GenBank database. The PCR products were sequenced in First Base, Malaysia. The phylogenetic tree was constructed by the same method as the previous.

\section{RESULTS AND DISCUSSION}

\section{Isolation of Sponge-associated-bacteria}

We have isolated 100 bacterial isolates from 5 different sponges, based on their distinct morphological characters. The abundance of bacterial isolates that were found varied amongst sponges and the isolation medium used (Figure 1). Indeed, total bacterial isolates that were isolated by using NA medium (62 isolates) were $12 \%$ higher than that SWC medium (38 isolates).

\section{Cellulolytic bacteria}

Amongst all 100 sponge-associated-bacteria tested, about 12 isolates showed cellulolytic activity (Table 1). The cellulolytic activity was determined by the development of a clear zone around the bacterial colony grown in CMC agar plate after reaction with Lugol's iodine reagent. Four isolates showed strong cellulolytic activity including CRN123, AGN103, AGN104, AGS111 with AGN 104, exhibited as the most potential cellulolytic bacteria (Figure 2).

\section{Laccase-producing bacteria}

Amongst 12 cellulolytic bacteria tested, only one laccase-producing bacteria (AGN89) was found. Laccase activity was determined by the development of reddishbrown color around the bacterial colony in the Guaiacol medium (Figure 3).

\section{Cellulolytic activity}

Cellulase enzyme activity of the four isolates was measured by using the DNS method. The highest cellulolytic activity and specific activity was exhibited by CRN123 isolate with a value of $0.06 \mathrm{UmL}^{-1}$ and $1.18 \mathrm{Umg}^{-}$ 1 , respectively (Table 2 ).

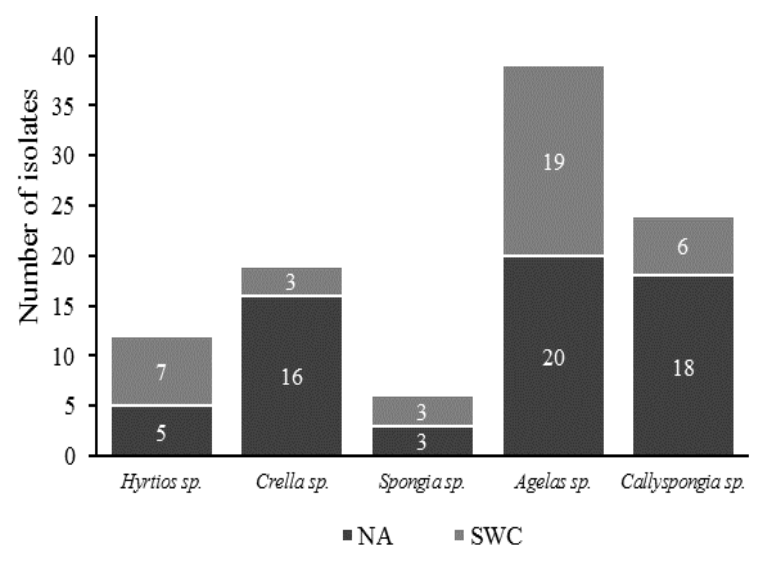

Figure 1. Distribution of sponge-associated bacterial isolates that were isolated from 5 sponges, using two different media. with incubation time 36 hours for NA and 48 hours for SWC at room temperature

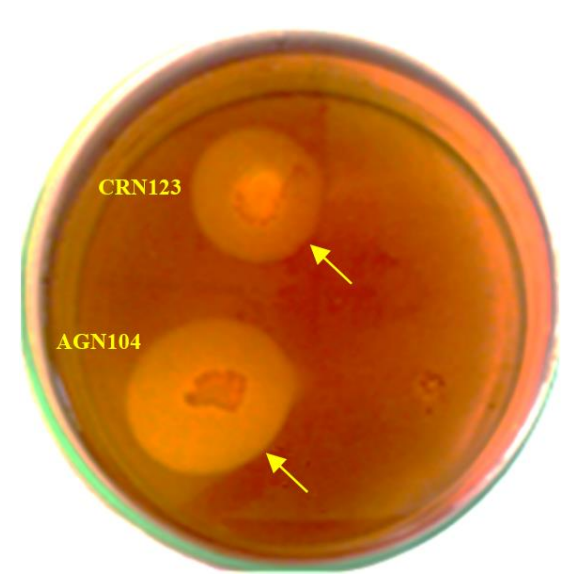

Figure 2. Cellulolytic activity of sponge-associated bacteria isolates (CRN123 and AGN2014) after 24 hours of incubation. Cellulolytic activity is shown by the development of the clear zone (arrow) around the bacterial colony grown in CMC-agar plate following reaction with Lugol's iodine reagent

Table 1. Cellulolytic index of sponge-associated bacteria

\begin{tabular}{llccc}
\hline Sponge & $\begin{array}{c}\text { Isolate } \\
\text { code }\end{array}$ & $\begin{array}{c}\text { Diameter of } \\
\text { colony } \\
\text { (mm) }\end{array}$ & $\begin{array}{c}\text { Diameter } \\
\text { of zone } \\
\text { (mm) }\end{array}$ & $\begin{array}{c}\text { Cellulolytic } \\
\text { Index }\end{array}$ \\
\hline Crella sp. & CRN123 & 4.25 & 7.50 & 0.76 \\
Agelas sp. & AGN81 & 4.00 & 6.25 & 0.57 \\
& AGN83 & 4.50 & 4.50 & 0.11 \\
& AGN89 & 4.12 & 5.52 & 0.37 \\
& AGN98 & 4.00 & 6.00 & 0.50 \\
& AGN100 & 3.75 & 5.50 & 0.47 \\
& AGN103 & 4.00 & 7.25 & 0.81 \\
& AGN104 & 4.12 & 7.75 & 0.88 \\
& AGN106 & 5.75 & 7.50 & 0.30 \\
& AGN107 & 3.75 & 5.50 & 0.47 \\
& AGS111 & 3.88 & 7.12 & 0.84 \\
Hyrtios sp. & HYN138 & 4.38 & 6.75 & 0.54 \\
\hline
\end{tabular}




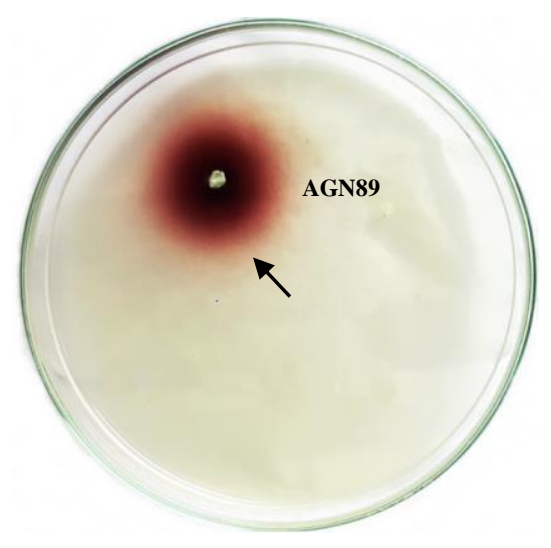

Figure 3. Laccase activity of bacterial isolate AGN89 grown in Guaiacol medium, after 48 hours of incubation at room temperature. Laccase activity is shown by the appearance of the reddish-brown zone (black arrow) around the bacterial colony.

Table 2. Cellulolytic activities of sponge-associated bacteria.

\begin{tabular}{lcc}
\hline Isolate code & $\begin{array}{c}\text { Activity } \\
\left(\mathbf{U m L}^{-1}\right)\end{array}$ & $\begin{array}{c}\text { Specific activity } \\
\left(\mathbf{U m g}^{-1}\right)\end{array}$ \\
\hline CRN123 & 0.06 & 1.18 \\
AGN103 & 0.04 & 0.70 \\
AGN104 & 0.05 & 0.71 \\
AGS111 & 0.05 & 0.81 \\
\hline
\end{tabular}

\section{Determination of Laccase activity based on gene analysis}

Amplification of laccase-encoding gene with PCR method has been successfully amplified a fragment with a length of $\pm 1100 \mathrm{bp}$ from isolate AGN89 genome (Figure 4). Alignment using the BlastX program revealed the laccase gene was similar to multicopper oxidase family protein which owned by Pseudomonas luteola with scores 99\% similarity, $99 \%$ query cover, and 0.0 E-value. All about this data result can be checked at the corresponding file with accession number WP 019364422 in NCBI GeneBank.

\section{The Identity based on 16S rRNA gene of the potential} cellulolytic and laccase-producing bacteria

In this assay, we analyzed the $16 \mathrm{~S}$ rRNA sequence of four cellulolytic and one laccase-producing isolate. Based on 16S rRNA sequence analysis each isolate was homolog to different genera of bacteria (Table 3).

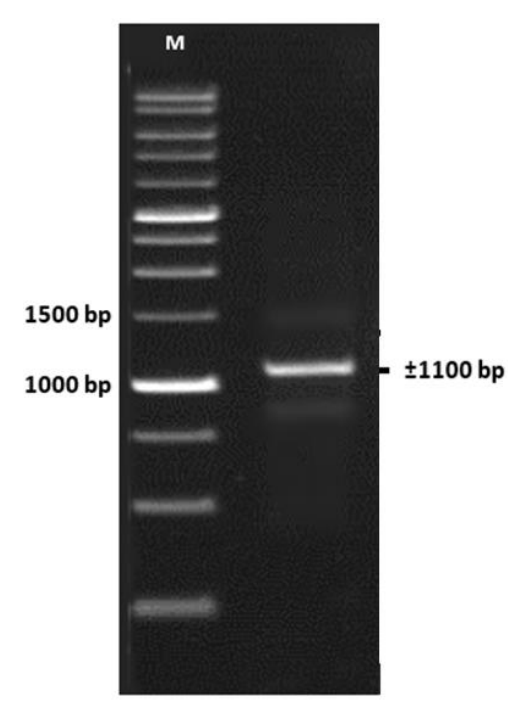

Figure 4. DNA band visualization by $1 \%$ agarose from amplicon of the laccase-encoding gene. M: Marker $1 \mathrm{~kb}$ ladder

The evolutionary relationship based on 16S rRNA of the potential bacterial isolates with their closest related strains is shown in Figure 5.

\section{Discussion}

A total of 100 sponge-associated bacteria from five sponges have been isolated in this study. Agelas sp. contributed the highest number of isolates contrarily to that sponge Spongia sp.. Different environmental and nutritional conditions of each sponge are thought to cause different bacterial communities (Santos-Gandelman et al. 2014). It is worth noting that, the two media used in this study resulted in a different number of isolated bacteria. We intentionally added $2 \% \mathrm{NaCl}$ in the medium to support the growth of marine bacteria to mimic the SWC medium composition. From our study, NA supports the growth of more number of bacterial isolates than that of SWC medium. It is likely due to NA medium was richer in nutrition than SWC medium. Some compositions, like yeast-extract and bactopeptone, are more contained in NA medium. These components were important as nutrition and respiration sources for the bacterial isolates to grow. Consequently, more bacteria could be grown by NA medium.

Table 3. BLAST-N-based homology analysis of sponge-associated bacteria based on 16S rRNA sequence gene

\begin{tabular}{llcccc}
\hline Isolate code & Closest relative & Query cover $(\%)$ & Similarity $(\%)$ & E-value & Accession \\
\hline CRN123 & B. aerius strain 24k & 99 & 97 & 0.0 & NR 118439 \\
AGN103 & P. aeruginosa strain DSM 50071 & 79 & 77 & 0.0 & NR 117678 \\
AGN104 & M. maritypicum strain DSM 20578 & 71 & 83 & 0.0 & NR 114986 \\
AGS111 & B. conglomeratum strain J 1015 & 61 & 84 & $6 \mathrm{e}-168$ & NR 104689 \\
AGN89 & P. luteola strain NBRC 102146 & 99 & 99 & 0.0 & NR 114215 \\
\hline
\end{tabular}




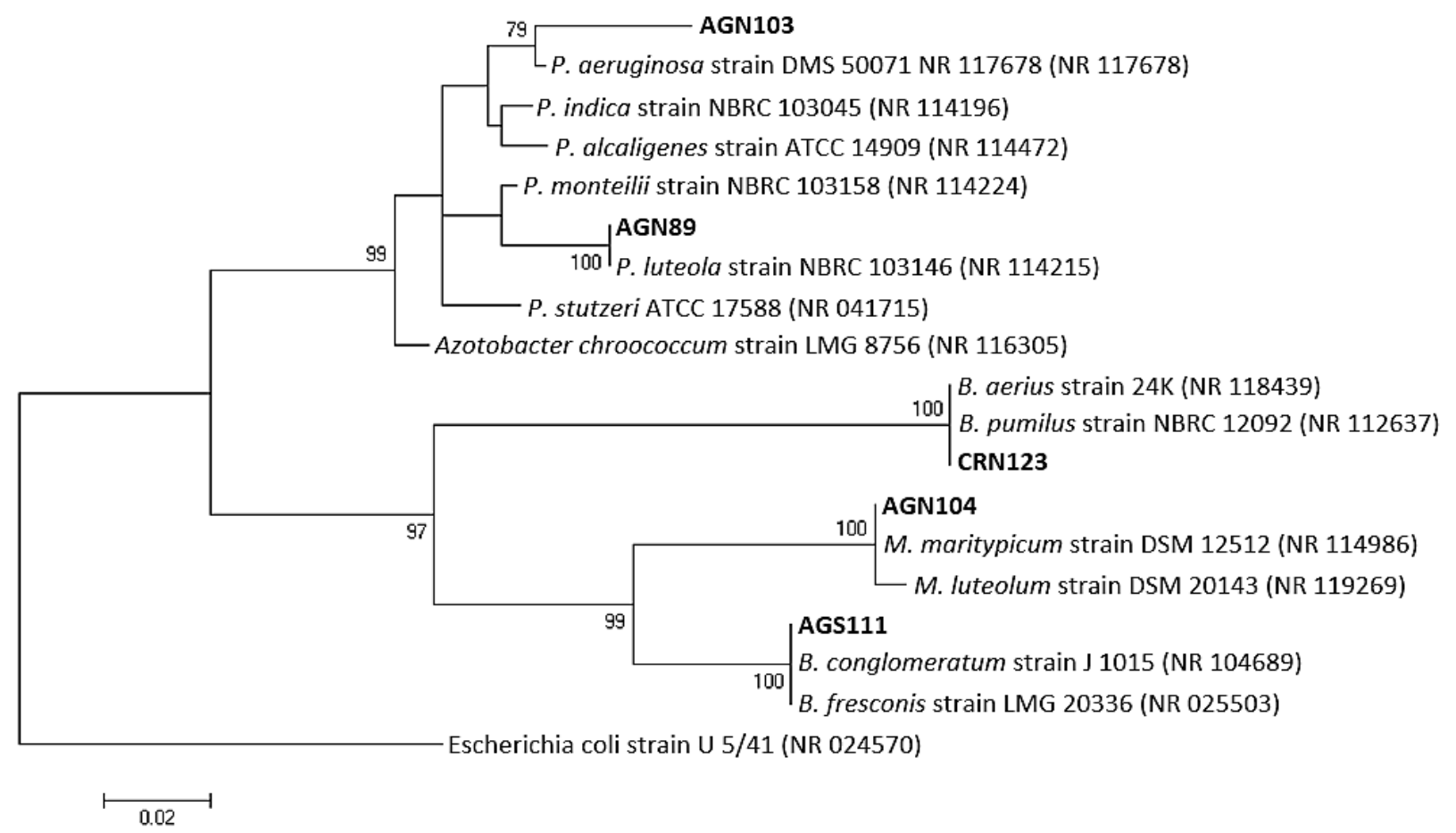

Figure 5. Maximum Likelihood phylogenetic representations of cellulase and laccase-producing bacteria with closest NCBI (BLAST) relatives based on 16S rRNA gene sequences. Bootstrap values calculated from 1000 resamplings using maximum likelihood are shown at the respective nodes when the calculated values were $50 \%$ or greater. The scale bar indicates $2 \%$ sequence divergence

Bacteria that are observed and isolated from sponges are commonly called symbionts, however, only few studies reported the clear indications of the beneficial interactions between bacteria and this particular sponge host. Sponges are sessile animals with no or little mechanical defense. Thus, sponges could likely utilize primary or secondary metabolites produced by bacterial symbionts as defensive systems against predators. Indeed, such interaction has been reported in sponge Microciona prolifera and it's associated bacteria (Imhoff and Stöhr 2003). Moreover, Santos-Gandelman et al. (2014) explained that the various activities exhibited by sponge-associated bacteria suggested that symbiotic microorganisms were indispensable for sponge survival. On the other hand, sponges may protect the symbionts bacteria from harmful environment and supply organic carbon compounds essential for bacterial metabolisms (Muller et al. 2004).

About twelve out of 100 isolates showed cellulolytic activity (Table 1). Their ability to produce cellulase was indicated by the clear zone formation around bacterial colonies in CMC medium (Figure 2). The primary metabolite produced by these bacteria were used to break down the complex cellulose compounds from the CMC medium. This process resulted in oligomers or monomers of derivated-sugar products which then can be used as their nutrients to grow. Cellulosic polysaccharides which should be able to bind to iodine dyes to form a color appearance will lose their ability to bind because they turn into monomers (or oligomers). This will change the area of the medium with the enzyme activity to become colorless (Kiio et al. 2016). Although Lugol's iodine staining was sensitive enough for primary isolation and screening of cellulolytic bacteria, the clear zone width was not implied the amount of cellulase activity (Samira et al. 2011). Hence, DNS method was used in this study for further quantify of cellulolytic activity.

Four isolates have been measured for the cellulolytic activity by the DNS method. These isolates exhibited about 0.04-0.06 $\mathrm{Uml}^{-1}$ and $0.70-1.18 \mathrm{Umg}^{-1}$ in enzyme and specific activities, respectively. These values were not much different from the cellulolytic activity of marine bacterial isolates that were isolated from Persian Gulf, which was about $0.08 \mathrm{UmL}^{-1}$ (Samira et al. 2011). However, these values were far below the value of cellulase activity owned by soil Bacillus $(0.167 \mathrm{U} / \mathrm{ml}$ and $0.333 \mathrm{U} / \mathrm{mg}$ in enzyme and specific activities, respectively) (Mahjabeen et al. 2018). Nevertheless, the marine enzymes offer many unique characters, one of them was a salttolerant thermostable character from Bacillus's cellulase isolated from coral Siderastrea stellata (dos Santos et al. 2018). Therefore, it is essential to explore new potential enzymes from diverse sources in tropical marine environments, including which of Indonesian marine environments.

Interesting result can be highlighted from laccase activity assay. One cellulolytic isolate, AGN89 isolate, had the ability to produce the laccase enzymes when tested on Guaiacol medium. Laccase activity in the medium was 
determined by the formation of reddish-brown areas (Figure 3) caused by the oxidative polymerization of Guaiacol (Atalla et al. 2010). The presence of this enzyme was also confirmed by the identification of the \pm 1100 amplicon fragment that has been amplified with PCR method (Figure 4). This amplicon was identified as multicopper oxidase family protein from $P$. luteola (and supported by the $16 \mathrm{~S}$ rRNA-based identification) (Table 3 ). This enzyme becomes interesting because it has never been reported before that sponge-associated bacteria can produce laccase enzymes. Most of bacterial laccase was isolated from terrestrial environment to date. Meanwhile, just a very limited study that reported bacterial laccase isolated from marine environment. The scarcity of this enzyme in the marine environment was reflected from this result, where only about $1 \%$ of all marine bacterial isolates gotten has laccase enzyme.

Based on the 16S rRNA gene sequence, the five potential marine bacterial isolates homolog to different genera of bacteria (Table 3). Some of them are possible as new species because according to Stackebrandt and Goebel (1994), the minimum similarity level of an isolate which can be stated as the same species to its BLAST result species is $97.5 \%$. Furthermore, the findings of varied sponge-associated bacteria with the cellulolytic ability in this study built the fact that there are still many sources that must be explored in the tropical ocean in Indonesia. Some studies reported several genera of Bacillus that produce unique cellulase have been successfully isolated from seaweed (Trivadi et al. 2011b, 2011b). Bacterial genera of Brachybacterium has also been successfully isolated from Euchema cottonii and had the ability to degrade lignocellulose (Santhi et al. 2014). Meanwhile, the genus Pseudomonas and Microbacterium in this study have not been widely reported in the last decade.

In conclusion, this is the first report on the isolation of sponge-associated bacteria from sponges, especially which obtained from Seribu Island Indonesia, that could produce laccase enzyme or both laccase and cellulase enzymes. Among 100 isolates isolated from marine sponges Crella sp., Agelas sp., Callyspongia sp., Hyrtios sp., and Spongia sp., one isolate had both cellulase and laccase enzymes and 11 isolates had cellulase enzyme with different cellulolytic index. Isolate CRN123 had the best value of enzyme and specific enzyme activities than others. Interestingly, in addition to cellulolytic activity, isolate AGN89 showed laccase activity based on the qualitative assay. Gene analysis suggested the gene likely responsible as laccaseencoding gene, belongs to that multicopper oxidase family protein. Further study is needed to develop these spongeassociated bacteria with their marine enzyme activities so that they could be characterized and applied in the industrial field.

\section{ACKNOWLEDGEMENTS}

We would like to express our appreciation to the Ministry of Research, Technology and Higher Education of the Republic of Indonesia for funding this work through the
Master program of Education Leading to a Doctoral Degree for Excellent Graduate ("Penelitian Magister menuju Doktor untuk Sarjana Unggul/PMDSU”) 2019 and Basics Research ("Penelitian Dasar") to ATW.

\section{REFERENCES}

Atalla MM, Zeinab HK, Eman RH, Amani A, Abeer A. 2010. Screening of some marine-derived fungal isolates for lignin-degrading enzymes (LDEs) production. Agric Biol J North Am 1 (4): 591-599.

Chandra R, Chowdhary P. 2015. Properties of bacterial laccases and their application in bioremediation of industrial wastes. Environ Sci Process Impacts 17: 326-342.

Chandra R, Singh R. 2012. Decolorization and detoxification of black liquor from rayon grade pulp paper mill effluent by mixed bacterial culture isolated from pulp paper mill effluent polluted site. Biochem Eng J 61: 49-58.

dos Santos YQ, de Veras BO, de França AFJ, Gorlach-Lira K, Velasques J, Migliolo L, dos Santos EA. A new salt-tolerant thermostable cellulase from a marine Bacillus sp. strain. J Microbiol Biotechnol 28 (7): 1078-1085.

Fang Z, Li T, Wang Q, Zhang X, Peng H, Fang W, Hong H, Ge H, Xiao Y. 2011. A bacterial laccase from marine microbial metagenome exhibiting chloride tolerance and dye decolorization ability. Appl Microbiol Biotechnol 89: 1103-1110.

Imhoff JR, Stöhr R. 2003. Sponge-associated bacteria: general overview and special aspects of bacteria associated with Halichondria panacea. Prog Mol Subcell Biol 37: 35-57.

Kiio IK, Jackim MF, Munyali WB, Muge EK. 2016. Isolation and characterization of a thermostable cellulase from Bacillus licheniformis strain vic isolated from geothermal wells in the Kenyan rift valley. Open Biotechnol J 10: 198-207.

Koschorreck K, Schmid RD, Urlacher VB. 2009. Improving the functional expression of a Bacillus licheniformis laccase by random and sitedirected mutagenesis. BMC Biotechnol 9: 12.

Kuhad RC, Gupta R, Singh A. 2011. Microbial cellulases and their industrial applications. Enzyme Res 2011: ID280696.

Madadi M, Tu1Y, Abbas A. 2017. Recent status on enzymatic saccharification of lignocellulosic biomass for bioethanol production. Electronic J Biol 13 (2): 135-143.

Mahjabeen F, Khan S, Choudhury N, Hossain MM, Khan T. 2018. Isolation of cellulolytic bacteria from soil, identification by $16 \mathrm{~S}$ rRNA gene sequencing and characterization of cellulase. Bangladesh J Microbiol 33 (1-2): 17-22.

Marchesi JR, Sato T, Weightman AJ, Martin TA, Fry JC, Hiom SJ, Wade WG. 1998. Design and evaluation of useful bacterium-specific PCR primers that amplify genes coding for bacterial 16S rRNA. Appl Environ Microbiol 64 (2): 795-799.

Miller GL. 1959. Use of dinitrosalicylic acid reagent for determination of reducing sugar. Anal Chem 31 (3): 426-428.

Muller WEG, Grebenjuk VA, Thakur NL, Thakur AN, Batel R. 2004. Oxygen-controlled bacterial growth in the sponge Suberites domuncula: toward a molecular understanding of the symbiotic relationships between sponge and bacteria. Appl Environ Microbiol 70: 2332-2341.

Piscitelli A, Pezzella C, Giardina P, Faraco V, Sannia G. 2010. Heterologous laccase production and its role in industrial applications. Bioeng Bugs 1 (4): 252-262.

Prastya ME, Astuti RI, Batubara I, Wahyudi AT. 2019. Antioxidant, Antiglycation and in vivo Antiaging Effect of Metabolite Extracts from Marine Sponge-Associated Bacteria on Fission Yeast. Ind J Pharm Sci 81 (2): 344-353.

Prastya ME, Astuti RI, Batubara I, Takagi H, Wahyudi AT. 2020. Chemical screening identifies an extract from marine Pseudomonas sp.-PTR-08 as an anti-aging agent that promotes fission yeast longevity by modulating the Pap1-ctt1+ pathway and the cell cycle. Mol Biol Rep 47 (1) : 33-43.

Priyanto JA, Astuti RI, Nomura J, Wahyudi AT. 2017. Bioactive compounds from sponge-associated bacteria: anticancer activity and NRPS-PKS gene expression in different carbon sources. Am J Biochem Biotechnol 13 (4): 158-156. 
Roth S, Spiess AC. 2015. Laccases for biorefinery applications: a critical review on challenges and perspectives. Bioprocess Biosyst Eng 38 (12): 2285-2313.

Samira M, Mohammad R, Gholamreza G. 2011. Carboxymethyl-cellulase and filter-paperase activity of new strains isolated from Persian Gulf Microbiol J 1 (1): 8-16.

Santhi VS, Bhagat AK, Saranya S, Govindarajan G, Jebakumar SRD. 2014. Seaweed (Eucheuma cottonii) associated microorganisms, a versatile enzyme source for the lignocellulosic biomass processing. Int Biodeterior Biodegrad 96: 144-151.

Santos-Gandelman JF, Giambiagi-deMarval M, Oelemann WMR, Laport MS. 2014. Biotechnological potential of sponge-associated bacteria. Curr Pharma Biotechnol 15: 143-155.

Sarkar S, Pramanik A, Mitra A, Mukherjee, J. 2010. Bioprocessing data for the production of marine enzymes. Marine Drugs 8: 1323-1372.

Shanmughapriya S, Kiran GS, Selvin J, Thomas TA, Rani C. 2010. Optimization, purification, and characterization of extracellular mesophilic alkaline cellulase from sponge-associated Marinobacter sp. MSI032. Appl Biochem Biotechnol 162 (3): 625-640.

Shanmughapriya S, Seghal KG, Selvin J, Gandhimathi R, Bastin BT, Manilal A, Sujith S. 2009. Optimization, production and partial characterization of an alkalophilic amylase produced by spongeassociated marine bacterium Halobacterium salinarum MMD047. Biotechnol Bioprocess Eng 14:67-75.

Stackebrandt E, Goebel BM. 1994. Taxonomic note: a place for DNADNA reassociation and $16 \mathrm{~S}$ rRNA sequence analysis in the present species definition in bacteriology. Int J Syst Evol Microbiol 44 (4): 846-849.

Trivedi N, Gupta V, Kumar M, Kumari P, Reddy CRK, Jha B. 2011a. Solvent tolerant marine bacterium Bacillus aquimaris secreting organic solvent stable alkaline cellulase. Chemosphere 83: 706-712.

Trivedi N, Gupta V, Kumar M, Kumari P, Reddy CRK, Jha B. 2011b. An alkali-halotolerant cellulase from Bacillus flexus isolated from green seaweed Ulva lactuca. Carbohydr Polym 83: 891-897.

Yoghiapiscessa D, Batubara I, Wahyudi T. 2016. Antimicrobial and antioxidant activities of bacterial extracts from marine bacteria associated with sponge Stylotella sp. Am J Biochem Biotechnol 12 (1): 36-46.

Wahyudi AT, Priyanto JA, Maharsiwi W, Astuti RI. 2018. Screening and characterization of sponge-associated bacteria producing bioactive compounds anti-Vibrio sp. Am J Biochem Biotechnol 14 (3): 221229. 